\title{
Аналіз застосування безпілотної авіації та армійської авіації під час бойової операції
}

\author{
Олександр Мальков ${ }^{1}$ А; Юрій Єльчанінов ${ }^{2}$ А; Олександр Лобас 3 А \\ А Національний університет оборони України імені Івана Черняховського, пр-кт Повітрофлотський 28, м. Київ, 03049, Україна
}

Received: August 21, 2021 | Revised: August 25, 2021 | Accepted: August 31, 2021

DOI: $10.33445 / s d s .2021 .11 .4 .13$

\begin{abstract}
Анотація
Стаття $€$ цікавою для професійних військових та дослідників, які займаються питаннями розвитку методів та способів застосування безпілотних літальних апаратів (БпЛА) у військових операціях. Метою статті $\epsilon$ аналіз застосування БпЛА у АзербайджаноВірменській війні (Друга карабахська війна) у 2020 році.

В статті наведено основні типи БпЛА, які були застосовані азербайджанськими військами в ході війни, а також розкрито їхні тактико-технічні характеристики. Наведено основні завдання армійської авіації щодо розвідки та постачання інформації в інтересах наземної компоненти та порівняно їх з можливостями БпЛА щодо виконання аналогічних завдань. 3'ясовано, що завданнями, які можуть виконувати БпЛА є: ведення повітряної оптикоелектронної розвідки; визначення координат, розмірів та інших характеристик об'єктів ураження (цілей) та коригування вогню артилерійських підрозділів; розвідка шляхів висування підрозділів та їх супроводження в ході висування; радіоелектронна боротьба; ретрансляція зв'язку в системах бойового управління; нанесення ураження військовим об'єктам тощо.
\end{abstract}

Ключові слова: бойовий потенціал, армійська авіація, безпілотний літальний апарат, розвідка, армійська авіація.

\section{Постановка проблеми}

Аналіз сучасних збройних конфліктів різного масштабу показує, що всі без виключення конфлікти супроводжуються використанням БпЛА. Такі тенденції вплинули на трансформацію способів, форм і методів ведення операцій та бойових дій, а завдання, які покладаються на безпілотну авіацію все більше говорять про ії універсалізацію адже вони починаються від розвідки і закінчуються ураженням військових та інфраструктурних об'єктів противника. В таких умовах надзвичайно важливим $€$ аналіз та систематизація інформації щодо форм та способів застосування БпЛА та їх тактико-технічних характеристик з метою розвитку вітчизняної тактики та оперативного мистецтва, а також виробництва та постачання на озброєння в Збройні Сили України сучасних БпЛА.

\section{Аналіз останніх досліджень та публікацій}

Питаннями, пов'язаними із різноманітними дослідженнями щодо застосування БпЛА для вирішення тактичних, оперативних та стратегічних завдань займалася низка українських та іноземних фахівців і вчених: І. Величко, І. М. Даценко, С. М. Ганін, Ю. К. Зіатдінов, І. С. Руснак, І. В. Матала, М. Антонов, О. М. Матусевич, С. П. Мосов, С. С. Невгад, Ю. М. Пащук, Ю. П. Сальник, М. Догерті, С. А. Станкевич, та ін.

\footnotetext{
${ }^{1}$ Corresponding author: старший викладач кафедри, e-mail: alexandr.sanych@gmail.com t, ORCID: 0000-0002-4303-1726

2 викладач кафедри, e-mail: yurii1971977@ukr.net, ORCID: 0000-0002-9624-3263

${ }^{3}$ старший науковий співробітник науково-дослідної лабораторії кафедри, e-mail: lobas1948@ukr.net, ORCID: 0000-0002-6864-4350
} 
Разом з цим, сучасні збройні конфлікти показують, що роль БпЛА у військових операціях все більше зростає, а завдання, які нею виконуються отримують все більшого розширення. Звідси, питання виявлення та ідентифікації умов, особливостей і проблемних питань застосування безпілотної авіації у воєнних конфліктах потребує проведення досліджень досвіду таких конфліктів на системній основі.

\section{Постановка завдання}

Метою статті $\epsilon$ аналіз застосування БпЛА у Азербайджано-Вірменській війні (Друга карабахська війна) у 2020 році, порівняння можливостей БпЛА та армійської авіації у виконанні аналогічних завдань.

\section{Виклад основного матеріалу}

Результати аналізу широкого спектру завдань повітряної розвідки та спостереження, що вирішувалися із застосуванням тактичної безпілотної розвідувальної авіації, викликали необхідність у систематизації умов, особливостей i проблемних питань їі застосування під час воєнних конфліктів.

Для початку увагу слід звернути на зброю та розвідувальне забезпечення вертолітних частин (підрозділів), яке здійснюється 3 метою своєчасного отримання розвідувальної інформації, необхідної для виконання ними завдань. Такий підхід дозволить в подальшому порівняти завдання армійської авіації та завдання, які здатні виконувати підрозділи безпілотної літальної авіації [1-3].

Основними завданнями розвідувального забезпечення $\epsilon$ :

здобування, обробка та надання в установленому порядку розвідувальної інформації для забезпечення прийняття рішень;

планування розвідувального забезпечення в інтересах ведення бойових дій;

контроль результатів авіаційних та інших ударів;

визначення погоди, ступеня радіоактивного та хімічного зараження атмосфери на маршрутах польотів і в районах бойових дій;

доведення розвідувальної інформації до об'єднань, з'єднань, частин та підрозділів під час підготовки та в ході ведення бойових дій.

Вертолітні підрозділи (екіпажі) ведуть повітряну розвідку (ПвР), з метою підвищення достовірності даних ПвР організовується взаємодія з органами управління розвідкою інших видів збройних сил (3С). ПвР в залежності від часу проведення і поставлених завдань поділяється на завчасну, дорозвідку та контрольну:

завчасна ПвР проводиться при наявності недостатньої розвідувальної інформації для планування операції (бойових дій);

дорозвідка проводиться для уточнення даних про положення і стан об'єктів, їх ППО, радіаційну обстановку, погоду на маршруті та в районах бойових дій, вона виконується, як правило, безпосередньо перед нанесенням ударів по рухомих об'єктах та перед висадкою повітряного десанту. Дорозвідка організовується штабом вертолітної частини (підрозділу) або вищим штабом;

контрольна ПвР проводиться в ході та після авіаційного удару для визначення його результатів, вона організовується штабом вертолітної частини (підрозділу), а за необхідності - вищим штабом.

Під час організації ПвР основна увага зосереджується на своєчасному доведенні розвідувальної інформації до зацікавлених посадових осіб. За організацію ПвР відповідає начальник штабу вертолітної частини (підрозділу). Безпосереднім організатором заходів ПвР є начальник розвідки.

Крім ПвР вертолітною частиною (підрозділом) ведеться наземна радіолокаційна розвідка. Вона виконується шляхом спостереження наземними радіоелектронними засобами за польотами авіації противника для своєчасного 
виявлення цілей, визначення їх належності та забезпечення командира розвідувальною інформацією.

Якщо аналізувати тактику застосування БпЛА, то вона постійно змінюється та вдосконалюється разом із доробками самих БпЛА та комплексного підходу до застосування різнорідних сил та засобів.

Цікавим і сучасним прикладом застосування БпЛА у воєнному конфлікті $\epsilon$ Друга карабахська війна. У Головному центрі управління збройними силами Азербайджанської Республіки для організації роботи із забезпечення застосування БпЛА в ході бойових дій була створена спеціальна чергова зміна, яка приймала рішення на бойове застосування як БпЛА, так і армійської авіації.

Варто зазначити, що азербайджанська сторона створила сучасну військову інфраструктуру для застосування різних типів БпЛА. Зокрема, на командному пункті Військово-Повітряних Сил (ВПС) Збройних Сил Азербайджанської республіки (АР) було сформовано підрозділ з операторів БпЛА, який здійснював безпосереднє управління БпЛА турецького ("Bayraktar ТВ2"), ізраїльського ("Harop", "Hermes 900", "SkyStriker") та азербайджанського (“Orbiter 1K", "Zerbe”) виробництва. 3 метою збільшення радіусу дії БпЛА “Bayraktar ТВ2", турецька компанія “Aselsan" встановила комунікаційні репітери на території Азербайджану (між м. Баку і Нагірним Карабахом), які підсилюють супутниковий зв'язок. Завдяки цьому значно вдалося збільшити радіус дії/польоту БпЛА (більше 300 KM).

Запуск БпЛА "Bayraktar TВ2" (інших типів БПЛА, які $є$ на озброєння ЗС АР) здійснювався з військового аеродрому, який розміщений в 230 км від м. Баку. Для цього використовується мобільна наземна станція управління БпЛА “Bayraktar ТВ2". Після підняття БПЛА на необхідну висоту, використовуючи потужні комунікаційні антени мобільних наземних станцій та репітери, управління БпЛА передавалося черговій зміні на командному пункті ВПС ЗС AP (м. Баку), в якому оператор направляв летальний апарат на визначений напрямок.

Кожному військовому підрозділу в ланці бригада, який залучався до проведення бойової операції з визволення територій, був прикомандирований офіцер з відповідного підрозділу ВПС ЗС АР. Зазначений офіцер, отримавши інформацію від штабу військового підрозділу (бригади) про необхідність застосування ударного БПЛА на відповідному напрямку, визначеним алгоритмом передавав необхідні відомості до чергової зміни командного пункту ВПС ЗС AP.

Наявні оптичні засоби, які встановлені на БПЛА “Bayraktar ТВ2", дозволили оператору здійснювати пошук цілей на відстані до 15 км. Після захоплення цілі та її супроводження, оператор БпЛА направляв запит до спеціально визначеної чергової групи офіцерів, які уповноваженні приймати рішення і надавати дозволи на застосування ударних БпЛА для знищення цілі. Здійснивши пуск високоточної ракети, оператор БпЛА супроводжував ціль до їі ураження.

Тактико-технічні характеристики БпЛА "Bayraktar TB2" дозволили на значній відстані знаходити та ідентифікувати цілі противника та в режимі он-лайн знищувати їх. БпЛА “Bayraktar ТВ2"обладнані системою Baykar Real Time Imagery Transmission System (BGAM), яка дозволяє передавати та обробляти зображення в реальному часі. Зокрема, BGAM забезпечує он-лайн трансляцію з високою роздільною здатністю без затримок декількома користувачам одночасно. BGAM - це веб-додаток, який дозволяє користувачам безпечно дивитися прямі трансляції в мережі або на планшетах за допомогою мобільного додатку через Інтернет. Система автоматично зберігає всі передані відеоматеріали в 30-хвилинні файли. Під час перегляду зображень, користувачі здатні робити нотатки 3 декількома тегами в системі.

Причиною пануючого становища азербайджанської сторони у повітрі було забезпечення знищення практично у повному обсязі системи ППО на всю глибину оборони зС Вірменії в Нагірному Карабасі. 
Необхідно зазначити, що ЗС $\mathrm{AP}$ застосували нову тактику виявлення та знищення ворожих засобів ППО. Напередодні бойових дій на військових аеродромах в АР базувались літаки типу Ан-2. Літаки були оснащені пристроями дистанційного керування. Водночас, зліт літака здійснював пілот. Після набрання необхідної висоти та виходу літака на заданий курс, пілот залишав літак шляхом стрибка з парашутом. Далі літак здійснював політ над контрольованою ворожою територією у супроводі ударних та розвідувальних БПЛА “Harop" або "Bayraktar ТВ2". Після ураження літака засобами ППО, ударні БПЛА завдавали удар по виявленим засобам ППО противника.

Також, слід відмітити вибіркове застосування ЗС АР пілотованої авіації, зокрема армійська авіація (вертольоти Мі-8, Mi-17, Мi-24 та Мi-35) після втрати у першій день початку бойових дій одного вертольоту $\mathrm{Mi}-8$, застосовувалась лише для супроводження і захисту з повітря великих військових колон та для евакуації поранених.

Вибіркове застосування армійської та штурмової авіації було обумовлене бажанням азербайджанської сторони мінімізувати ризики втрат. Всього за період бойових дій ВПС АР втратили один вертоліт Мі-8.

Щодня вертольотами “Мі-8" та "Мі-17" здійснювалось 2-3 польоти для постачання боєприпасів і вивозу поранених.

Армійська авіація також застосовувалась для проведення пошуково-рятувальних операцій. Ці операції проводились як 3 бойових порядків авіаційних груп, так і в стані чергування на визначених майданчиках i аеродромах. До складу екіпажів чергових вертольотів залучались штатні пошуковорятувальні групи. При проведенні пошуковорятувальних операцій з використання вертольотів “Мі-8” та “Мi-17", їх в обов'язковому порідку прикривали ударні вертольоти "Мi-24V"/“Mi-24G".

Таким чином, можна стверджувати, що однією з особливостей бойових дій в Нагірному Карабасі стало те, що військова компанія продемонструвала зниження ролі підрозділів армійської авіації та зростання значення застосування БпЛА та іншої високоточної зброї.

Для більш чіткого розуміння можливостей БпЛА, що застосовувалися ЗС АР у війні необхідно здійснити аналіз їхніх тактикотехнічних можливостей.

Ударний оперативно-тактичний середньовисотний БпЛА “Bayraktar ТВ2" розроблений приватною турецькою компанією "Baykar Makina". Перші тестові польоти проведені у 2014 році. В тому ж році, зазначені БпЛА використовувалися в проведені бойових операцій в східних провінціях Туреччини [4].

Вартість експортного варіанту 1-го комплексу (в один комплекс входить три літальних апарати) БпЛА складає 4-5 млн. дол. США, для потреб ЗС Туреччини - вартість складає орієнтовно 2 млн. дол. США.

Для ударних БпЛА "Bayraktar ТВ2" турецька компанії "Rocketsan" розробила високоточні міні ракети "MAM-L" та "MAM-C" 3 лазерним наведенням. Одночасно на одному БпЛА можливо встановити 4 високоточні боєприпаси (рис. 1). Максимальне корисне навантаження складає 150 кг [5].

Тактико-технічні характеристики MAM-L

\begin{tabular}{|l|c|}
\hline Вага ракети, кг: & 22,5 \\
\hline Тип боєголовки: & термобалістичні, кумулятивна тандемна, осколково- \\
& фугасна \\
\hline Вага бойової частини, кг: & $8 / 10$ \\
\hline Довжина, мм: & 800 \\
\hline Діаметр, мм: & 160 \\
\hline Дальність ураження цілі, км : & до 14 \\
\hline
\end{tabular}




\begin{tabular}{|c|c|}
\hline \multicolumn{2}{|c|}{ Тактико-технічні характеристики МАМ-С } \\
\hline Вага ракети, кг: & 8,5 \\
\hline Вага бойової частини, кг: & 2,5 \\
\hline Довжина, мм: & 1000 \\
\hline Діаметр, мм: & 70 \\
\hline Дальність ураження цілі, км: & від 0,5 до 8 \\
\hline
\end{tabular}

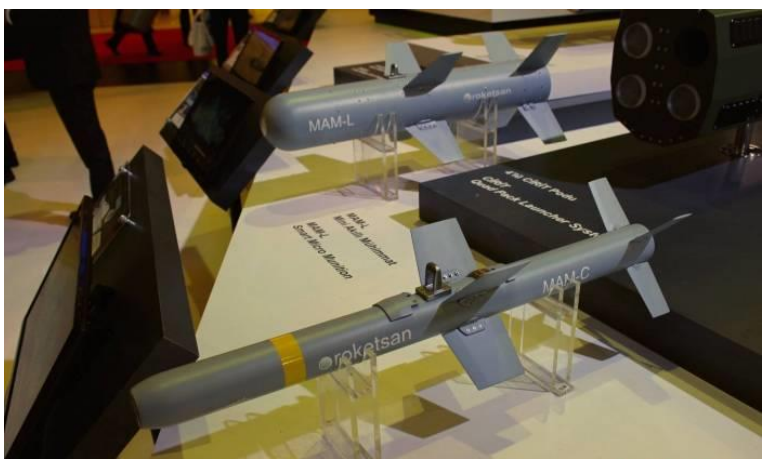

Рисунок 1 - Високоточні міні ракети “MAM-L” та "MAM-C"

БпЛА-камікадзе "Zerbe-1K" (рис. 2). Виробляється на азербайджанському заводі "AZAD Systems" по ліцензії ізраїльської компанії Aeronautics Defense Systems. БпЛА "Zerbe-1K" має збільшений радіус дії та може використовувати високоточні боєприпаси.

Завод "AZAD Systems" підпорядкований Міністерству оборонної промисловості Азербайджанської Республіки. Це азербайджансько-ізраїльське спільне підприємство. Завод збудований у березні 2011 року ізраїльськими фахівцями спеціально для збирання БпЛА на території Азербайджану. Орієнтовна вартість контракту на будівництво заводу "AZAD Systems" - 400 млн. дол. США.

Вартість одного БпЛА "Zerbe-1K" орієнтовно складає до 70 тис. дол. США [6].

БпЛА “Zerbe” призначений для боротьби з піхотою та легко броньованою рухомою та нерухомою технікою противника. Апарат здатен знайти ціль у визначеному районі, супроводжувати їі та знищити по команді оператора у будь-який час доби. Для цього БпЛА оснащений оптико-електронною системою спостереження у звичайному та інфрачервоному діапазонах, системою управління польотом, яка забезпечує ручне пілотування апаратом або автоматичне баражування за програмою.

БпЛА-камікадзе "Zerbe" може діяти на відстані до 100 км і рухатись зі швидкістю до 130 км/год на висоті до 5500 м впродовж 2-3 годин.

Ціль вражається осколочно-фугасною бойовою частиною вагою 2,5 кг. Під час вибуху створюється хмара з радіусом до $25 \mathrm{M}$. Підрив може здійснюватися у повітрі, 3 тимчасовою затримкою, або при контакті 3 ціллю.

Зліт БпЛА здійснюється за допомогою катапульти, приземлення - за допомогою парашута і надувної камери. Під час польоту оператор визначивши ціль переводить БпЛА у режим пікірування. Апарат має малий акустичний шум і тому може бути поміченим лише за 2 секунди до ураження цілі. За необхідністю атака цілі може бути відмінена, а сам апарат буде поверненим до місця старту. Мобільність застосування БпЛА забезпечується шляхом розміщення апарату на борту броньованої машини азербайджанського виробництва "K1-Zerbe" (рис. 3).

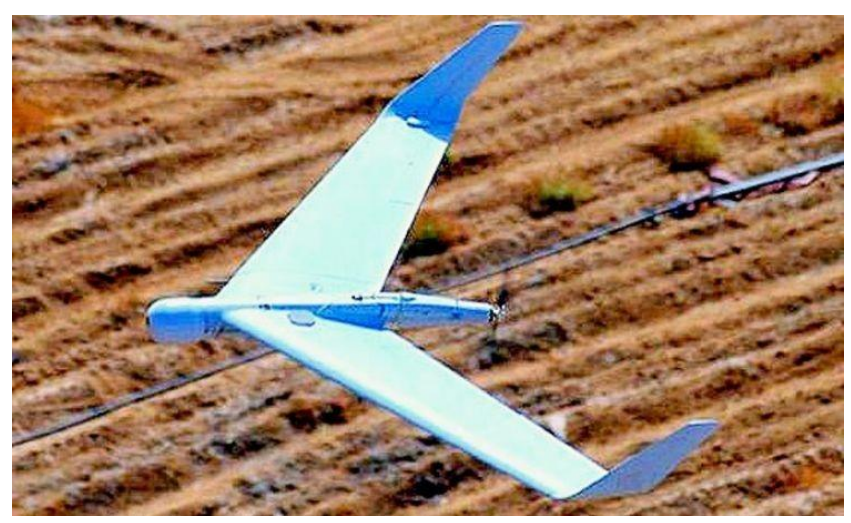

Рисунок 2 - Загальний вигляд "Zerbe-1K" (“Orbiter-1K") у польоті 


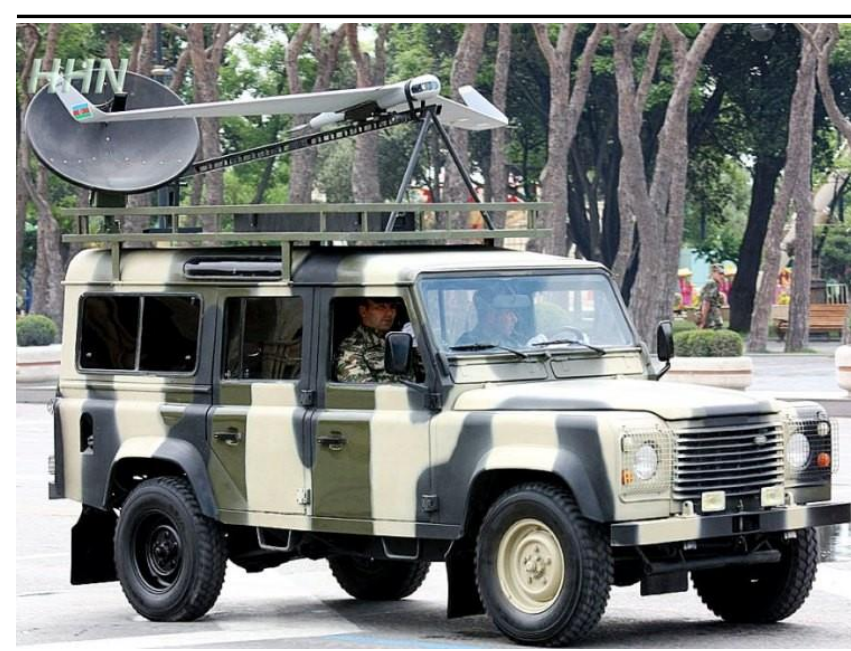

Рисунок 3 - БпЛА "Zerbe-1K" (“Orbiter-1K") на броньованій машині “K1-Zarba”

Ударний БпЛА “ZERBE-5” [7]. Ударний БПЛА "ZERBE-5" виробляється на азербайджанському заводі "AZAD Systems" по ліцензії ізраїльської компанії Aeronautics Defense Systems. Перший такий апарат азербайджанського виробництва був випробуваний 21 червня 2017 року.

Ударний БпЛА “ZERBE-5" здатен знайти ціль у заданому районі, супроводжувати ії та знищити по команді оператора у будь-який час доби. Для цього БпЛА оснащений оптикоелектронною системою спостереження у звичайному та інфрачервоному діапазоні, системою управління польотом, яка забезпечує ручне пілотування апаратом або автоматичне баражування за програмою.

Ударний БпЛА “ZERBE-5” (рис. 4) оснащений 4 самонавідними ракетами типу SVN-380 “повітря-земля” 3 лазерним прицілом (вага кожної з ракет - до 180 кг).

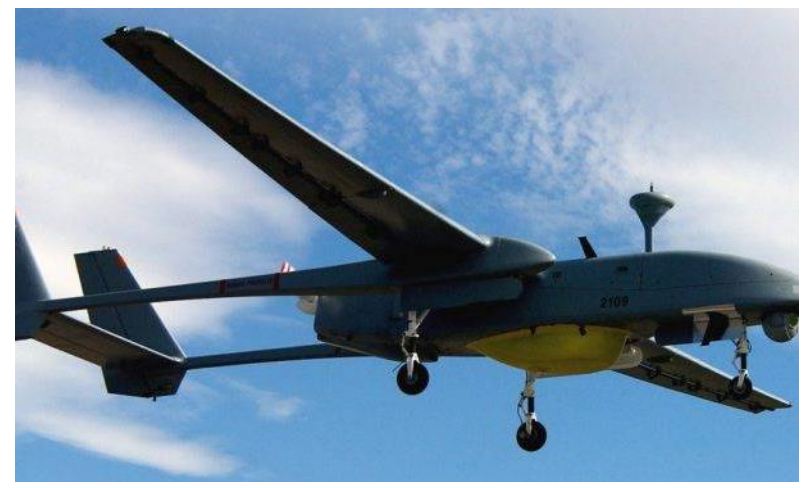

Рисунок 4 - Загальний вигляд ударного БпЛА "Zerbe-5"
БпЛА-камікадзе “Нагор”. БПЛА-камікадзе "Harop" були закуплені для потреб ЗС АР в Ізраїлі. Перше їх бойове застосування азербайджанськими військовим відбулось у період 2-5 квітня 2016 року під час бойових дій з Вірменією.

БпЛА-камікадзе "Harop" обладнаний радаром і цифровою камерою з кутом огляду 360 градусів, що має високу здатність. Особливістю цього БпЛА $€$ те, що при виявленні цілі апарат "перетворюється" у самонавідний літак-снаряд. БПЛА-камікадзе "Нагор" здатний тривалий час здійснювати патрулювання визначеного району i знищувати наземні цілі за командою. При заході на ціль команда на ії ураження може бути скасована і БПЛА повернеться на базу або продовжить патрулювання. Швидкість БПЛА-камікадзе “Нагор" - до 185 км/год. Дальність польоту - до 1000 км.

БпЛА-камікадзе “Наap" цілі знищує осколочно-фугасною бойовою частиною вагою 2,5 кг. Під час вибуху створюється хмара з радіусом до 25 м. Крім того, підрив бойової частини БпЛА може здійснюватися у повітрі, з тимчасовою затримкою, або при контакті з ціллю.

БпЛА “Hermes 900” [8]. БпЛА “Hermes 900” - всепогодний тактичний безпілотний літальний апарат, розроблений ізраїльською компанією Elbit Systems. Перший політ зробив в грудні 2009 року. Серійне виробництво ведеться в Ізраїлі з середини 2010 року.

БПЛА “Hermes 900", з максимальною злітною вагою в 970 кілограм і 15-ти метровими крилами, може нести корисне навантаження в 300 кг. "Hermes 900" $\epsilon$ всепогодним безпілотним апаратом. В БпЛА встановлена система автоматичного зльоту і посадки. Як і “Hermes 450”, який відомий своєю неперевершеною безпекою i надійністю, “Hermes 900”, відповідає найвищим вимогам, які пред'являють до безпілотних апаратів.

“Hermes 900" контролюється 3 землі універсальною станцією управління Elbit Systems UGCS, яка здатна одночасно керувати двома безпілотними апаратами. У носовій 
частині БпЛА може бути розміщена система супутникового зв'язку, що дозволяє контролювати безпілотник на віддалених від зон прямого зв'язку площах (рис. 5).

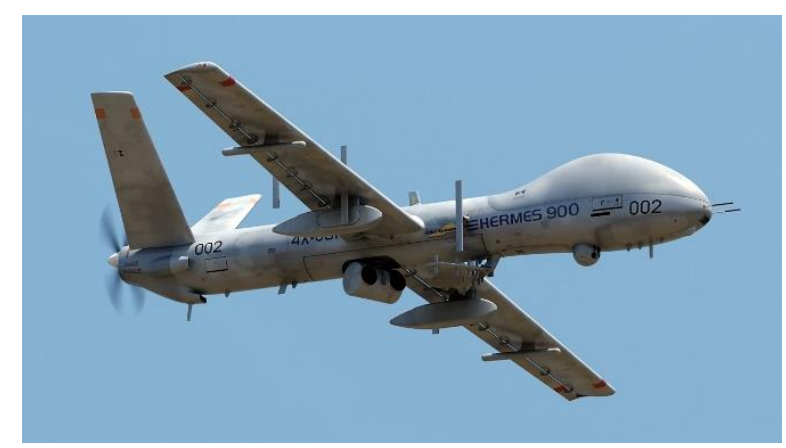

Рисунок 5 - Загальний вигляд ударного БпЛА “Hermes 900" у польоті.

БПЛА "SkyStriker" (рис. 6). БПЛА "SkyStriker" вперше був представлений на початку вересня 2016 року. "SkyStriker" призначений для нанесення тактичних ударів по противнику на великій відстані. БПЛА "SkyStriker" являє собою літальний апарат 3 пропелером і електродвигуном. Вага - 35 кг, бойова частина має масу від 5 до 10 кг. Дрон, який озброєний боєголовкою вагою в 5 кг може знаходиться у повітрі до 2 години [9].
Максимальна швидкість становить 185 км/г (до 190 км/г), а в момент пікірування на ціль - до 500 км/г.

БпЛА "SkyStriker" обладнаний електричною системою руху 3 низькою акустичною помітністю, що дозволяє проводити приховані операції на малих висотах. Озброєння застосовує автономну навігаційну систему. Оператор БпЛА має можливість перервати атаку, відходити, і знову атакувати ті ж або інші цілі. БпЛА "SkyStriker" може бути повернутий на будьякому етапі операції, 3 використанням парашута і надувного мішка.

Запускається БпЛА "SkyStriker" 3 використанням унікальної пускової установки, яку можна буксирувати на автомобілі.

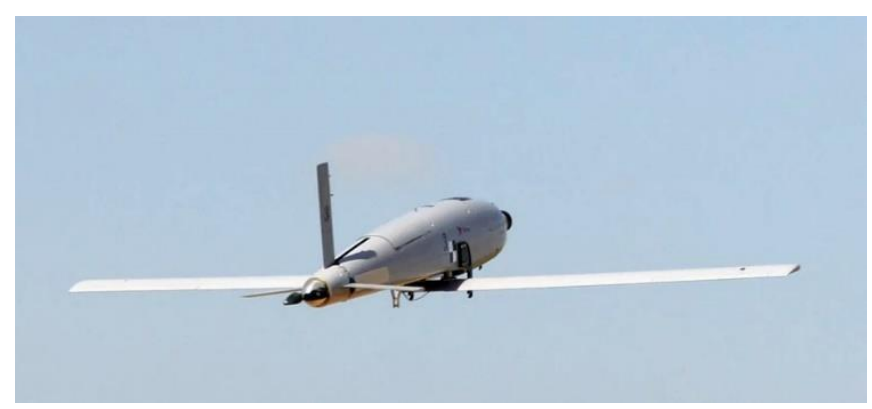

Рисунок 6 - Загальний вигляд ударного БПЛА "SkyStriker" у польоті

\section{Висновки}

Таким чином набуває розвитку тенденція використання БпЛА у воєнних конфліктах. Тактико-технічні характеристики сучасних БпЛА дозволяють їм виконувати значну частину завдань які ще десятиліття тому покладалися на армійську та тактичну авіацію. До таких завдань можна віднести наступні: повітряна розвідка; виявлення та супроводження цілей; наведення на цілі артилерії та високоточної зброї; підсилення засобів зв' язку; постановка радіоелектронних перешкод; удари по військових та інфраструктурних об'єктах противника тощо. У зв'язку з меншою вартістю використання
БпЛА та більшою безпекою для особового складу, у порівнянні з армійською авіацією, вони будуть все більше набувати популярності, а спектр їхніх завдань буде розширюватися. Але не слід зменшувати значення армійської авіації адже такі завдання, як пошуково-евакуаційні, десантні, повітряні вантажні перевезення залишаться за армійською авіацією. Враховуючи можливості сучасних БпЛА можна констатувати, що спільне їх використання 3 армійською авіацією може підвищити ефективність повітряної компоненти сухопутних військ 3С.

\section{Список використаних джерел}

1. Бойовий статут сухопутних військ армійська авіація Сухопутних військ
Збройних сил України

2. Тактика армійської авіації : навч. посібник, 
частина 1, Харківський університет Повітряних Сил імені Івана Кожедуба, 2017

3. Тактика армійської авіації : навч. посібник, частина 2, Харківський університет Повітряних Сил імені Івана Кожедуба, 2017.

4. Оновлена версія комплексу Bayraktar TB2 з радіусом дії 300 кілометрів стане частиною системи стримування російської агресії. URL: https://armyinform.com.ua/2021/07/ onovlena-versiya-kompleksu-bayraktar-tv2z-radiusom-diyi-300-kilometriv-stanechastynoyu-systemy-strymuvannyarosijskoyi-agresiyi/ (дата звернення 05.08.21)

5. Турецкий ударный беспилотник Bayraktar TB2. URL: https://topwar.ru/176027tureckij-udarnyj-bespilotnik-bayraktartb2.html. (дата звернення 05.08.21)

6. Беспилотники Азербайджана. Orbiter и
Aerostar. URL: https://militarizm.su/vojna-vkarabahe/bespilotniki-azerbajdzhanaorbiter-i-aerostar.html (дата звернення 01.08.21)

7. Беспилотники в боевых действиях в Нагорном Карабахе. URL: https://books.google.ru/books?id=JNcmEAA AQBAJ\&pg=PT10\&dq=\%22Azad +systems\%2 $2 \& \mathrm{hl}=$ ru\&newbks $=1 \&$ newbks_redir $=0 \& s a=X$ \&ved=2ahUKEwi6ieKujtnxAhWys4sKHd4sCO 4Q6AEwAXoECAcQAg\#v=onepage $\& q=\% 22 \mathrm{Az}$ ad\%20systems\%22\&f=false (дата звернення 04.08.21)

8. Hermes $^{\text {TM }} \quad 900 . \quad$ URL: https://elbitsystems.com/product/hermes900-5/ (дата звернення 05.08.21)

9. SkyStriker. URL: https://elbitsystems.com/ media/SkyStriker.pdf (дата звернення 03.08.21)

\section{Анализ применения беспилотной авиации и армейской авиации во время боевой операции}

\footnotetext{
Александр Мальков * 1 А; Юрий Єльчанинов 2 А; Александр Лобас 3 А Corresponding author: * ${ }^{1}$ старший преподаватель кафедры, e-mail: alexandr.sanych@gmail.com, ORCID: 0000-0002-4303-1726 ${ }^{2}$ преподаватель кафедры, e-mail: yurii1971977@ukr.net, ORCID: 0000-0002-9624-3263

${ }^{3}$ старший научный сотрудник научно-исследовательской лаборатории кафедры, e-mail: lobas1948@ukr.net, ORCID: 0000-0002-6864-4350

А Национальный университет обороны Украины имени Ивана Черняховского, пр-кт Воздухофлотский, 28, г. Киев, 03049, Украина Аннотация

Статья интересна для профессиональных военных и исследователей, занимающихся вопросами развития методов и способов применения беспилотных летательных аппаратов (БПЛА) в военных операциях. Целью статьи является анализ применения БПЛА в Азербайджано-армянской войне (Вторая карабахская война) в 2020 году.

В статье приведены основные типы БПЛА, которые были применены азербайджанскими войсками в ходе войны, а также раскрыто их тактико-технические характеристики. Приведены основные задачи армейской авиации по разведке и поставки информации в интересах наземной компоненты и сравнительно их с возможностями БПЛА по выполнению аналогичных задач. Выяснено, что задачами, которые могут выполнять БПЛА являются: ведение воздушной оптико-электронной разведки; определения координат, размеров и других характеристик объектов поражения (целей) и корректировки огня артиллерийских подразделений; разведка путей выдвижения подразделений и их сопровождение в ходе выдвижения; радиоэлектронная борьба; ретрансляция связи в системах боевого управления; нанесения поражения военным объектам и тому подобное.
}

Ключевые слова: боевой потенциал, армейская авиация, беспилотный летательный аппарат, разведка, армейская авиация.

\section{Analysis of the use of unmanned aviation and army aviation during a combat operation}




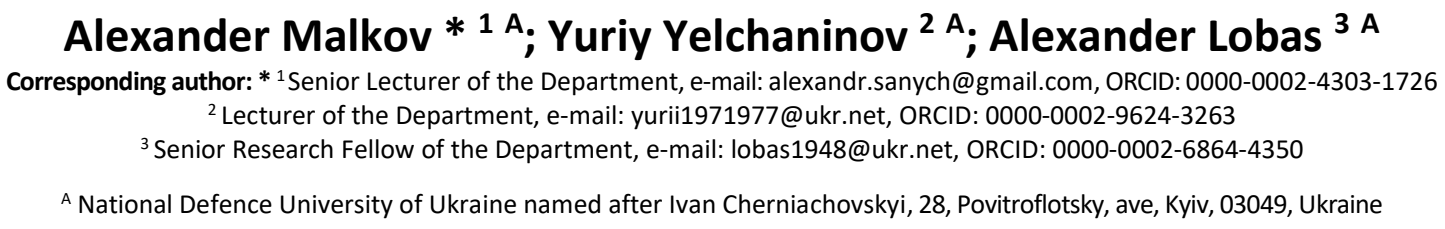

\begin{abstract}
The article is interesting for professional military and researchers who are engaged in the development of methods and methods for using unmanned aerial vehicles (UAVs) in military operations. The purpose of the article is to analyze the use of UAVs in Azerbaijan-Armenia War (Second Karabakh War) in 2020.

The article presents the main types of UAVs that were applied to Azerbaijan troops during the war, as well as their tactical and technical characteristics are revealed. The main tasks of the Army aviation on intelligence and supply of information in the interests of the terrestrial component and are relatively with the capabilities of the UAVs on the implementation of similar tasks are presented. It has been found that tasks that can perform UAV are: air opto-electronic intelligence; determination of coordinates, sizes and other characteristics of objects of damage (goals) and adjusting the fire of artillery units; exploration of ways to nominate units and their support in the course of nomination; Radio-electronic struggle; retransmission of communication in combat management systems; application by military facilities, etc.
\end{abstract}

Keywords: battle potential, army aviation, unmanned aerial vehicle, exploration, army aviation.

\title{
References
}

1. Boyovyy statut sukhoputnykh viys'k armiys'ka aviatsiya Sukhoputnykh viys'k Zbroynykh syl Ukrayiny

2. Taktyka armiys'koyi aviatsiyi : navch. Posibnyk, chastyna 1, Kharkivs'kyy universytet Povitryanykh Syl imeni Ivana Kozheduba, 2017

3. Taktyka armiys'koyi aviatsiyi : navch. Posibnyk, chastyna 2, Kharkivs'kyy universytet Povitryanykh Syl imeni Ivana Kozheduba, 2017

4. Onovlena versiya kompleksu Bayraktar TV2 z radiusom diyi 300 kilometriv stane chastynoyu systemy strymuvannya rosiys'koyi ahresiyi. Available from : https://armyinform.com.ua/2021/07/onovle na-versiya-kompleksu-bayraktar-tv2-zradiusom-diyi-300-kilometriv-stanechastynoyu-systemy-strymuvannyarosijskoyi-agresiyi/ (data zvernennya 05.08.21)

5. Turetskyy udarnyy bespylotnyk Bayraktar TB2. Available from : https://topwar.ru/176027-tureckij-udarnyj- bespilotnik-bayraktar-tb2.html.

(data zvernennya 05.08.21)

6. Bespylotnyky Azerbaydzhana. Orbiter y Aerostar. Available from https://militarizm.su/vojna-vkarabahe/bespilotniki-azerbajdzhanaorbiter-i-aerostar.html (data zvernennya 01.08.21)

7. Bespylotnyky $v$ boevykh deystvyyakh $v$ Nahornom Karabakhe. Available from : https://books.google.ru/books?id=JNcmEAA AQBAJ\&pg=PT10\&dq $=\% 22$ Azad + systems $\% 2$ $2 \& \mathrm{hl}=$ ru\&newbks $=1 \&$ newbks_redir $=0 \& s a=X$ \&ved=2ahUKEwi6ieKujtnxAhWys4sKHd4sCO 4Q6AEwAXoECAcQAg\#v=onepage $\& q=\% 22 A z$ ad\%20systems\%22\&f=false (data zvernennya 04.08.21)

8. Hermes $^{\mathrm{TM}}$ 900. Available from : https://elbitsystems.com/product/hermes900-5/ (data zvernennya 05.08.21)

9. SkyStriker. Available from https://elbitsystems.com/media/SkyStriker. pdf (data zvernennya 03.08.21) 